\title{
Phosphorus requirements of tambaqui juveniles
}

\section{Exigência de fósforo para juvenis de tambaqui}

\author{
Thalles José Rêgo de Sousa ${ }^{1 *}$; Marcos Antonio Delmondes Bomfim²; Eduardo \\ Arruda Teixeira Lanna ${ }^{3}$; Felipe Barbosa Ribeiro²; Jefferson Costa de Siqueira²; \\ Janayra Cardoso Silva ${ }^{1}$; Rafael Silva Marchão ${ }^{1}$
}

\begin{abstract}
The aim of this study was to determine the requirement of digestible phosphorus in diets for juvenile tambaqui (Colossoma macropomum). 300 juveniles $(26.4 \pm 0.68 \mathrm{~g})$ were used in a completely randomized design, consisting of six treatments with five replicates and 10 fish per experimental unit. The treatments consisted of six isoprotein, isonitrogenous, and isocalcium rations, with different levels of digestible phosphorus: $0.27 ; 0.46 ; 0.67 ; 0.91 ; 1.04$; and $1.14 \%$. The fish were kept in 30 polyethylene tanks $(500 \mathrm{~L})$ with a closed water circulation system and fed six meals per day for 49 days. Parameters of performance and feed efficiency, daily protein, and fat, ash, and phosphorus deposition rates were evaluated. The elevation of digestible phosphorus provided a quadratic increase in feed consumption to a level of $0.92 \%$, linear increase in the consumption of digestible phosphorus, and quadratic reduction in the efficiency of digestible phosphorus for weight gain. The linear response plateau model was the best fit for weight gain and specific growth rate, estimated at $0.55 \%$ and $0.56 \%$ digestible phosphorus, respectively. The feed conversion and protein efficiency for weight gain improved quadratically up to an estimated level of $0.84 \%$ of digestible phosphorus. Body fat deposition improved quadratically up to an estimated level of $0.90 \%$ of digestible phosphorus. The linear response plateau model was the best fit for body deposition of protein, ash, and phosphorus, estimated at $0.55 \%, 0.46 \%$, and $0.59 \%$ of digestible phosphorus, respectively. To optimize weight gain, the recommended level of digestible phosphorus in diets for juvenile tambaqui is $0.55 \%$, which corresponds to an estimated level of $0.87 \%$ of total phosphorus.
\end{abstract}

Key words: Aquaculture. Colossoma macropomum. Fish nutrition. Minerals. Nutritional requirement.

\section{Resumo}

Objetivou-se determinar a exigência de fósforo digestível em rações para juvenis de tambaqui (Colossoma macropomum). Utilizou-se 300 juvenis $(26,4 \pm 0,68 \mathrm{~g})$ em delineamento inteiramente casualizado, composto por seis tratamentos, cinco repetições e dez peixes por parcela. Os tratamentos constituíram-se de seis rações isoproteicas, isoenergéticas e isocálcicas, com diferentes níveis de fósforo digestível $(0,27 ; 0,46 ; 0,67 ; 0,91 ; 1,04 ;$ e $1,14 \%)$. Os peixes foram mantidos em 30 caixas de polietileno de $500 \mathrm{~L}$ em sistema fechado de circulação de água e alimentados em seis refeições diárias durante 49 dias. Avaliaram-se parâmetros de desempenho e eficiência alimentar, taxas de deposição diária de proteína, gordura, cinzas e fósforo corporais. A elevação dos níveis de fósforo digestível proporcionou

1 Discentes, Programa de Pós-Graduação em Ciência Animal, Universidade Federal do Maranhão, UFMA, Campus IV Chapadinha, Chapadinha, MA, Brasil. E-mail: E-mail: talesrego@hotmail.com; janayrasilva.c@gmail.com; rafaelmarchao@yahoo.com.br

2 Profs., Curso de Zootecnia, UFMA, Campus IV Chapadinha, Chapadinha, MA, Brasil. E-mail: madbomfim@yahoo.com.br; felipebribeiro@yahoo.com; jcsiqueira@ufma.br

3 Prof., Departamento de Zootecnia, Universidade Federal de Viçosa, UFV, Viçosa, MG, Brasil. E-mail: elanna@ufv.br

* Author for correspondence 
aumento de forma quadrática no consumo de ração até o nível de $0,92 \%$, aumento linear no consumo de fósforo digestível, e redução de forma quadrática na eficiência de fósforo digestível para o ganho de peso dos peixes. Para o ganho de peso e taxa de crescimento específico dos peixes, o modelo Linear Response Plateau foi o que melhor se ajustou aos dados, estimando em $0,55 \%$ e $0,56 \%$ o nível de fósforo digestível a partir dos quais ocorreram os platôs. A conversão alimentar e a eficiência proteica para o ganho de peso melhoraram de forma quadrática até o nível estimado de $0,84 \%$ de fósforo digestível, respectivamente. A deposição gordura corporal de forma quadrática até o nível estimado de $0,90 \%$ de fósforo digestível. Para as deposições corporais de proteína e cinzas e fósforo, o modelo Linear Response Plateau foi o que melhor se ajustou aos dados, estimando em $0,55 \%, 0,46 \%, 0,59 \%$ o nível de fósforo digestível a partir dos quais ocorreram os respectivos platôs. Concluiu-se que a recomendação dos níveis de fósforo digestível em rações para juvenis de tambaqui é de $0,55 \%$, por otimizar o ganho de peso, que corresponde ao nível estimado de $0,87 \%$ de fósforo total.

Palavras-chave: Aquicultura. Colossoma macropomum. Exigência nutricional. Minerais. Nutrição de peixes.

\section{Introduction}

The tambaqui (Colossoma macropomum) is a native Brazilian species widely used in fish farming. It is the second-most cultivated species in Brazilian aquaculture and has a broad economic importance. Besides enjoying a marked acceptability by consumers, due to the quality and taste of its flesh, the species has high growth rates, hardiness, and ease of adaptation to intensive production systems, as well as the ability to tolerate low levels of dissolved oxygen (DAIRIKI; SILVA, 2011; RODRIGUES, 2014; GUIMARÃES; MARTINS, 2015).

Among the nutritionally required minerals, phosphorus is one of the most limiting minerals used in the production of ration. This mineral is essential for the formation of bone structure, cell membranes, phosphoproteins, energy transfer, regulation of acidbase equilibrium, and in enzymatic and hormonal systems involved in the metabolism of amino acids, carbohydrates, and fat (QUINTERO-PINTO et al., 2011; SANTOS, 2012). When present at levels below the nutritional requirement, phosphorus leads to reduced performance, feed efficiency, and bone mineralization. However, when at levels that meet the requirements, it improves protein utilization and bone mineralization, and allows a reduction in lipid deposition. However, if the mineral contents are above the animal's requirement, the efficiency of its use decreases considerably, increasing its excretion. Phosphorus is the first limiting factor for the growth of aquatic algae: excess phosphorus, excreted by farmed animals, stimulates eutrophication and results in deterioration of water quality (CYRINO et al., 2010; XIE et al., 2017). Therefore, it is essential to accurately determine the phosphorus requirement to minimize its excess without promoting deficiency in farmed fish (RIBEIRO et al., 2006; TANG et al., 2012; ARAÚJO et al., 2017).

The nutritional requirements of phosphorus indicate that there is a significant variation in the recommended values among species and between growth phases of the same species (FURUYA et al., 2010; NRC, 2011; FRACALOSSI; CYRINO, 2013). However, the feed industries use recommendations with higher levels than the studies suggest, without considering species-specific nutritional requirements (FURUYA et al., 2010; CYRINO et al., 2010).

Given the lack of information regarding the requirement of phosphorus in rations for tambaqui, and that this mineral's dietary requirement varies at different growth stages, this study aimed at determining the requirement of digestible phosphorus in feed for juvenile tambaqui.

\section{Material and Methods}

The experiment abided by the ethical standards for research with animals, after being approved by the Ethics Committee on Animal Use at 
the Federal University of Maranhão (Protocol: 23115008833/2014-31). The study was conducted for 49 days in the Agricultural and Environmental Sciences Center Aquatic Organism Food and Nutrition Laboratory at the Federal University of Maranhão in Chapadinha.

We used 300 juvenile tambaqui, with an initial weight of $26.49 \pm 0.68 \mathrm{~g}$, in an experiment with a completely randomized block design, consisting of six treatments, with five replicates per treatment and 10 fish per experimental unit. The treatments consisted of six experimental isoproteic (32\% crude protein), isoenergetic (3000 kcal of digestible energy), and isocalcium rations, with different levels of digestible phosphorus: $0.27 ; 0.46 ; 0.67 ; 0.91 ; 1.04$; and $1.14 \%$ (Table 1 ). The levels of digestible phosphorus were based on the digestibility coefficients of soybean meal and dicalcium phosphate recommended for Nile tilapia by Furuya et al. (2010). The levels of crude protein, methionine plus cystine:lysine, and threonine:lysine were fixed, based on the values recommended by Lima (2013) and Souza (2014) for tambaqui, and by Takishita (2012) for Nile tilapia, respectively. For the other nutritional levels, we used the values recommended for Nile tilapia per NRC (2011).

Table 1. Percent chemical composition of the experimental rations (natural matter).

\begin{tabular}{|c|c|c|c|c|c|c|}
\hline \multirow{2}{*}{ Ingredients $(\%)$} & \multicolumn{6}{|c|}{ Level of digestible phosphorus (\%) } \\
\hline & 0.27 & 0.46 & 0.67 & 0.91 & 1.04 & 1.14 \\
\hline Soybean meal & 66.082 & 66.082 & 66.082 & 66.082 & 66.082 & 66.082 \\
\hline Corn & 19.645 & 19.645 & 19.645 & 19.645 & 19.645 & 19.645 \\
\hline Soy oil & 6.460 & 6.460 & 6.460 & 6.460 & 6.460 & 6.460 \\
\hline Inert & 2.087 & 1.670 & 1.252 & 0.835 & 0.417 & 0.000 \\
\hline Lysine-HCl & 0.111 & 0.111 & 0.111 & 0.111 & 0.111 & 0.111 \\
\hline DL-Methionine & 0.266 & 0.266 & 0.266 & 0.266 & 0.266 & 0.266 \\
\hline L-Threonine & 0.405 & 0.405 & 0.405 & 0.405 & 0.405 & 0.405 \\
\hline Calcitic limestone & 3.874 & 3.099 & 2.324 & 1.550 & 0.775 & 0.000 \\
\hline Dicalcium phosphate & 0.000 & 1.192 & 2.385 & 3.577 & 4.769 & 5.961 \\
\hline Vitamin and mineral premix ${ }^{1}$ & 0.500 & 0.500 & 0.500 & 0.500 & 0.500 & 0.500 \\
\hline Vitamin $\mathrm{C}^{2}$ & 0.050 & 0.050 & 0.050 & 0.050 & 0.050 & 0.050 \\
\hline Salt & 0.500 & 0.500 & 0.500 & 0.500 & 0.500 & 0.500 \\
\hline Antioxidant (BHT) & 0.020 & 0.020 & 0.020 & 0.020 & 0.020 & 0.020 \\
\hline \multicolumn{7}{|c|}{ Calculated composition $^{3}$} \\
\hline Crude protein $(\%)$ & 32.00 & 32.00 & 32.00 & 32.00 & 32.00 & 32.00 \\
\hline Digestible protein $(\%)^{4}$ & 29.34 & 29.34 & 29.34 & 29.34 & 29.34 & 29.34 \\
\hline Digestible energy $\left(\mathrm{kcal} \mathrm{kg}^{-1}\right)^{4}$ & 3000.0 & 3000.0 & 3000.0 & 3000.0 & 3000.0 & 3000.0 \\
\hline Ether extract $(\%)$ & 8.27 & 8.27 & 8.27 & 8.27 & 8.27 & 8.27 \\
\hline Crude fiber $(\%)$ & 3.84 & 3.84 & 3.84 & 3.84 & 3.84 & 3.84 \\
\hline Total Ca (\%) & 1.62 & 1.62 & 1.62 & 1.62 & 1.62 & 1.62 \\
\hline Calculated total P (\%) & 0.42 & 0.64 & 0.86 & 1.08 & 1.30 & 1.52 \\
\hline Total P analyzed (\%) & 0.57 & 0.78 & 1.00 & 1.25 & 1.39 & 1.50 \\
\hline Digestible $\mathrm{P}(\%)^{4}$ & 0.27 & 0.46 & 0.67 & 0.91 & 1.04 & 1.14 \\
\hline
\end{tabular}


continuation

\begin{tabular}{lllllll} 
Digestible lysine $(\%)^{4}$ & 1.700 & 1.700 & 1.700 & 1.700 & 1.700 & 1.700 \\
Digestible Methionine + Cystine (\%) & 1.105 & 1.105 & 1.105 & 1.105 & 1.105 & 1.105 \\
Digestible threonine (\%) & 1.496 & 1.496 & 1.496 & 1.496 & 1.496 & 1.496 \\
Digestible tryptophan $(\%)^{4}$ & 0.405 & 0.405 & 0.405 & 0.405 & 0.405 & 0.405 \\
\hline
\end{tabular}

*Total phosphorus obtained by laboratory analysis

${ }^{1}$ vitamin and mineral supplement $\left(5 \mathrm{~kg} \mathrm{t}^{-1}\right)$, with guaranteed levels per kilogram of product: Vit. A, 1,200,000 IU; Vit. D 3 , 200,000

IU; Vit. E, 1,200 mg; Vit. K , 2,400 mg; Vit. B, 4,800 mg; Vit.B , 4,800 mg; Vit. B, 4,800 mg; Vit. B ${ }_{12}, 4,800$ mg; Vit. C, 48.00 $\mathrm{mg}$; folic acid, 1,200 mg; Ca pantothenate, 12,000 mg; biotin, $48 \mathrm{mg}$; choline chloride, $108 \mathrm{~g}$; niacin, 24,000 mg; Fe, 50,000 mg; $\mathrm{Cu}, 3,000 \mathrm{mg}$; Mn, 20,000 mg; Zn, 30,000 mg; I, 100 mg; Co, 10 mg; Se, 100 mg.

${ }^{2}$ Vit. C: Calcium L-Ascorbic acid 2-monophosphate, $42 \%$ of active ingredient;

${ }^{3}$ Based on the values proposed by Rostagno et al. (2011);

${ }^{4}$ Based on the coefficients of digestibility proposed for Nile tilapia by Furuya et al. (2010).

For the pre-experimental, adaptation period (1 week), the fish were stocked in the experimental installations and fed with commercial ration. In the experimental period, the fish were kept in 30 polyethylene tanks $(500 \mathrm{~L})$ with a closed water circulation system, additional aeration, and individual drainage. Tanks were cleaned daily by siphonage, always after monitoring the temperature of the water.

The water temperature was monitored daily at 0730 and $1730 \mathrm{~h}$, using a mercury bulb thermometer graduated from 0 to $50{ }^{\circ} \mathrm{C}$. The $\mathrm{pH}$ levels, dissolved oxygen content, and water ammonia were monitored every 7 days with a pHmeter, pulse oximeter, and commercial kit to test for toxic ammonia, respectively. Water quality parameters were kept within the recommended standards during the experimental period (MENDONÇA et al., 2012). The maximum and minimum water temperatures remained around $28.2 \pm 0.64{ }^{\circ} \mathrm{C}$ and $26.1 \pm 0.78^{\circ} \mathrm{C}$ respectively. The concentration of dissolved oxygen was around $8.73 \pm 0.75 \mathrm{ppm}$, with $\mathrm{pH} 6.0 \pm 0.46$ and total ammonia $\leq 1.00 \mathrm{ppm}$.

The ingredients of the experimental rations were mixed, moistened in water, heated to approximately $50{ }^{\circ} \mathrm{C}$ and pelletized using a meat grinder. Then, the rations were dried, crushed, and sieved, obtaining pellets of 3 to $4 \mathrm{~mm}$ in diameter. The rations were offered six times a day $(0800,1000,1200,1400$,
1600 , and $1800 \mathrm{~h})$. At each feeding time, the rations were offered in small quantities, with successive passes to apparent satiation, thus avoiding leftovers or under-delivery.

At the end of the experiment, after 24 hours of fasting, all the fish in each tank were weighed, stunned, euthanized, and frozen. Thereafter, the final biometrics of the fish and the consumption of feed per experimental unit were measured. We evaluated various indices for performance and feed efficiency: feed consumption, consumption of digestible phosphorus, weight gain, specific growth rate, feed conversion, protein efficiency for weight gain, and efficiency of phosphorus for weight gain. The parameters of performance and feed efficiency were calculated according to the equations:

- Feed consumption $(\mathrm{g})$ = ration consumed during the experimental period;

- Consumption of digestible phosphorus (mg) = [feed consumption $(\mathrm{mg}) \times$ digestible phosphorus content of the ration $(\%)] / 100$;

- Weight gain $(\mathrm{g})$ = final average weight - initial average weight;

- Specific growth rate $\left(\%\right.$ day $\left.^{-1}\right)=[($ natural logarithm of final weight $(\mathrm{g})$ - natural logarithm of initial weight $(\mathrm{g})) \times 100] /$ experimental period (days);

- Feed conversion $\left(\mathrm{g} \mathrm{g}^{-1}\right)=$ feed intake / weight gain; 
- Protein efficiency for weight gain $\left(\mathrm{g} \mathrm{g}^{-1}\right)=$ weight gain / consumption of crude protein; and

- Efficiency of phosphorus for weight gain $\left(\mathrm{g} \mathrm{g}^{-1}\right)$ = weight gain / consumption of total phosphorus.

Samples of fish at the beginning (approximately $50 \mathrm{~g}$ ) and at the end of the experiment (six fish per experimental plot, with weights corresponding to the average weight of the respective unit) were dried in an oven with forced air circulation, predegreased, milled in a ball mill, and analyzed for their body composition (moisture, protein, fat, ash, and phosphorus) per Detmann et al. (2012). The laboratory analyses of carcasses and diets were performed at the Federal University of Maranhão and the Federal University of Piauí. In addition, based on body composition, the rates of daily deposition of body protein, fat, and phosphorus were calculated per Bomfim et al. (2010) and Ribeiro et al. (2006):

- Deposition of body protein $\left(\mathrm{mg} \mathrm{day}^{-1}\right)=[$ (quantity of final body protein $(\mathrm{mg})$ - quantity of initial body protein $(\mathrm{mg})$ )] / (period of experimental observation);

- Deposition of body fat $\left(\mathrm{mg}\right.$ day $\left.^{-1}\right)=[$ (quantity of final body fat (mg) - (quantity of initial body fat $(\mathrm{mg}))]$ / (period of experimental observation);

- Deposition of body phosphorus $\left(\mathrm{mg}\right.$ day $\left.^{-1}\right)=$ [(quantity of final body phosphorus (mg) - quantity of initial body phosphorus (mg))] / (period of experimental observation); and

- Deposition of body ash $\left(\mathrm{mg} \mathrm{day}^{-1}\right)=[$ (quantity of final body ash (mg) - quantity of initial body ash $(\mathrm{mg}))]$ / (period of experimental observation).
Statistical analyses were performed using SAS software 9.0 (SAS, 2002). The data were subjected to analysis of variance with a significance of 0.05 . For the variables that displayed significant effects of digestible phosphorus by variance analysis, linear and quadratic regression analyses were performed. The discontinuous linear response pPlateau (LRP) model was also evaluated. The best fit model was chosen considering the $\mathrm{P}$ value (significance) and the coefficient of determination $\left(\mathrm{R}^{2}\right)$ (model sum of squares/ sum of treatment squares).

\section{Results and Discussion}

Rising levels of phosphorus in the diet influenced all performance variables $(\mathrm{P}<0.05)$. The quadratic model $(\mathrm{P}<0.05)$ had a better fit for the consumption of fish ration according to the elevation of digestible phosphorus, until an estimated level of $0.92 \%$. Thus, the best balance was provided by elevating dietary phosphorus, which increased feed consumption and utilization of nutrients. Consequently, this influenced the significant effects observed in other variables. The consumption of digestible phosphorus increased linearly $(\mathrm{P}<0.01)$ with the elevation of digestible phosphorus in the ration (Tables 2 and 3). In experiments with tilapia, dietary levels of phosphorus did not have a defined response pattern on feed consumption. Furuya et al. (2008a) observed a quadratic reduction in feed consumption when they evaluated the effects of diets containing different levels of available phosphorus for juveniles (35 to $100 \mathrm{~g}$ ). Ribeiro et al. (2006) in turn, found no variation in consumption of ration by fingerlings (0.60 to $4.00 \mathrm{~g})$. 
Table 2. Ration consumption (RC), consumption of digestible phosphorus (CDP), weight gain (WG), specific growth rate (SGR), feed conversion (FC), protein efficiency for weight gain (PEW), and efficiency of phosphorus for weight gain (EPW) of juvenile tambaqui per level of digestible phosphorus, and summary of the analysis of variance.

\begin{tabular}{|c|c|c|c|c|c|c|c|}
\hline \multirow{2}{*}{$\begin{array}{c}\text { Level of digestible } \\
\text { phosphorus }(\%)\end{array}$} & \multicolumn{7}{|c|}{ Variable } \\
\hline & $\mathrm{RC}(\mathrm{g})$ & CDP (mg) & WG (g) & SGR $\left(\%\right.$ day $\left.^{-1}\right)$ & $\mathrm{FC}\left(\mathrm{g} \mathrm{g}^{-1}\right)$ & $\operatorname{PEW}\left(\mathrm{g} \mathrm{g}^{-1}\right)$ & EPW $\left(\mathrm{g} \mathrm{g}^{-1}\right)$ \\
\hline 0.27 & 52.08 & 0.14 & 51.02 & 2.17 & 1.02 & 3.06 & 369.56 \\
\hline 0.46 & 52.71 & 0.24 & 58.98 & 2.38 & 0.89 & 3.49 & 244.36 \\
\hline 0.67 & 60.40 & 0.40 & 67.34 & 2.58 & 0.90 & 3.48 & 166.76 \\
\hline 0.91 & 56.55 & 0.51 & 59.46 & 2.38 & 0.95 & 3.28 & 116.00 \\
\hline 1.04 & 58.80 & 0.61 & 64.51 & 2.54 & 0.91 & 3.43 & 105.89 \\
\hline 1.14 & 57.85 & 0.66 & 64.47 & 2.52 & 0.90 & 3.47 & 97.61 \\
\hline $\mathrm{P}>\mathrm{F}^{1}$ & 0.0371 & $<0.0001$ & 0.0203 & 0.0058 & 0.0003 & $<0.0001$ & $<0.0001$ \\
\hline $\mathrm{CV}(\%)^{2}$ & 8.99 & 10.26 & 11.76 & 6.58 & 4.46 & 4.70 & 4.80 \\
\hline
\end{tabular}

${ }^{1} \mathrm{P}>\mathrm{F}$ - Significance of F-test for analysis of variance

${ }^{2} \mathrm{CV}$ - Coefficient of variation.

Table 3. Adjusted regression equations $P$ values, coefficients of determination $\left(R^{2}\right)$, and requirement percentages for ration consumption (RC), consumption of digestible phosphorus (CDP), weight gain (WG), specific growth rate (SGR), feed conversion (FC), protein efficiency for weight gain (PEW), and efficiency of phosphorus for weight gain (EPW) of juvenile tambaqui.

\begin{tabular}{lccccc}
\hline Variable & Model & Equation & $\mathrm{P}>\mathrm{F}$ & $\mathrm{R}^{2}$ & Requirement (\%) \\
\hline RC $(\mathrm{g})$ & Linear & $\mathrm{RC}=51.1464+7.05121 \mathrm{P}$ & 0.0277 & 0.51 & ----- \\
RC $(\mathrm{g})$ & Quadratic & $\mathrm{RC}=44.433+30.757 \mathrm{P}-16,783 \mathrm{P}^{2}$ & 0.0409 & 0.67 & 0.92 \\
$\mathrm{CDP}(\mathrm{mg})$ & Linear & $\mathrm{CDP}=0.214888+0.602044 \mathrm{P}$ & 0.0001 & 0.99 & ----- \\
WG $(\mathrm{g})$ & Quadratic & $\mathrm{WG}=38.36+60.2030 \mathrm{P}-34.116 \mathrm{P}^{2}$ & 0.0099 & 0.70 & 0.88 \\
WG $(\mathrm{g})$ & LRP $^{1}$ & $\mathrm{WG}=62.8113-40.5588(0.5544-\mathrm{P})$ & 0.0074 & 0.80 & 0.55 \\
SGR $\left(\%\right.$ day $\left.^{-1}\right)$ & Quadratic & $\mathrm{SGR}=1.868+1.46618 \mathrm{P}-0.8160 \mathrm{P}^{2}$ & 0.0041 & 0.70 & 0.90 \\
SGR $\left(\%\right.$ day $\left.^{-1}\right)$ & LRP $^{1}$ & $\mathrm{SGR}=2.4789-1.004(0.5638-\mathrm{P})$ & 0.0014 & 0.80 & 0.56 \\
FC $\left(\mathrm{g} \mathrm{g}^{-1}\right)$ & Quadratic & $\mathrm{FC}=1.101+0.47544 \mathrm{P}-0.28262 \mathrm{P}^{2}$ & 0.0106 & 0.48 & 0.84 \\
PEW $\left(\mathrm{g} \mathrm{g} \mathrm{g}^{-1}\right)$ & Quadratic & $\mathrm{PEW}=2.798+1.599 \mathrm{P}-0.9540 \mathrm{P}^{2}$ & 0.0179 & 0.46 & 0.84 \\
EPW $\left(\mathrm{g} \mathrm{g} \mathrm{g}^{-1}\right)$ & Quadratic & $\mathrm{EPW}=568.613-878.454 \mathrm{P}+412.571 \mathrm{P}^{2}$ & 0.0001 & 0.99 & ---- \\
\hline
\end{tabular}

${ }^{1}$ LRP - linear response plateau.

A similar response pattern to that of feed consumption was also observed in weight gain and specific growth rate. Despite the quadratic increase in both variables $(\mathrm{P}<0.05)$, the LRP model was the best fit for the data, at an estimated level of $0.55 \%$ (Tables 2 and 3, Figure 1). Pezzato et al. (2006) and Furuya et al. (2008b) also reported a quadratic increase in weight gain and specific growth rate in Nile tilapia fed with increasing available phosphorus up to 0.97 and $0.55 \%$, respectively. Rocha et al. (2010) observed an improvement in the specific growth rate of Argentinian silverside up to a level of $0.43 \%$ of available phosphorus in the diet. According to Yao et al. (2014), the addition of phosphorus in juvenile Nile tilapia diets linearly improved weight gain and promoted a quadratic effect on the specific growth rate until a concentration of $0.86 \%$. 
Figure 1. Tambaqui juvenile weight gain per level of digestible phosphorus.

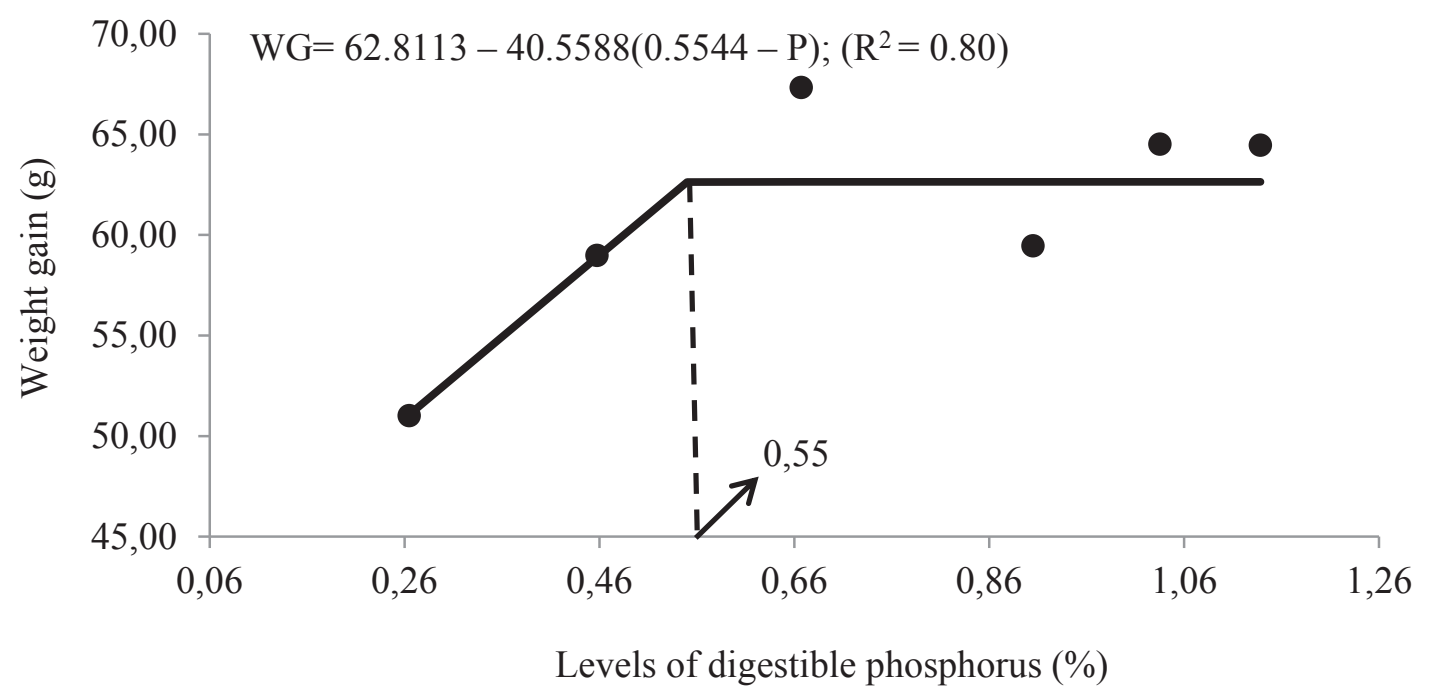

The results for weight gain and specific growth rate of fish fed with diets containing levels below $0.55 \%$ of digestible phosphorus indicate that levels below the requirements limit animal growth. This mineral directly influences metabolic rate and deposition of protein, fat tissue, and bone tissue, as well as the efficiency of protein retention (LALL; LEWIS-MCCREA, 2007; PRABHU et al., 2013), minimizing the excretion of nitrogenous wastes to the environment (BOMFIM, 2013). The increase in feed intake may have been directly related to the proportional increase in nutritional demand (nutrients and energy) to meet the needs of maintenance and a higher growth rate of animals provided with higher levels of this mineral (NOBLET, 2001; BENSTEAD et al., 2014).

On the other hand, there was a tendency toward a reduction in feed intake, growth, and feed efficiency in fish fed diets with levels higher than $0.67 \%$ of digestible phosphorus. These effects may be due to evolutionary adaptations of some fish species reared in environments containing low phosphorus content. Thus, these species may be less likely to adapt to the ingestion of foods with excessive phosphorus (BOERSMA; ELSER, 2006) and develop physiological mechanisms to effectively use the phosphorus from foods of vegetable origin (BENSTEAD et al., 2014; ARAÚJO et al., 2017).

The food conversion values decreased $(\mathrm{P}<0.01)$ and protein efficiency for weight gain increased $(\mathrm{P}<$ 0.01 ), both quadratically, depending on the elevation of digestible phosphorus in feed, improving these variables until the estimated level of $0.84 \%$ (Tables 2 and 3). The reduction in the feed conversion ratio indicates that the best balance, provided by the elevation of digestible phosphorus, also influences the utilization efficiency of nutrients and/or energy. This is similar to what was observed by Furuya et al. (2008b), in studies with juvenile Nile tilapia, and Pimentel-Rodrigues and Oliva-Teles (2001) in studies with juvenile Gilthead seabream. This efficiency may be related to the increase in protein deposition, since the deposition of lean tissue is more energy efficient than fat deposition. The proportional increase may also be due to the use of nutritional components for production, relative to that which is intended for maintenance (BUREAU et al., 2000; NOBLET, 2001; SAKOMURA; ROSTAGNO, 2007; SIQUEIRA et al., 2009).

On the other hand, the efficiency of phosphorus for weight gain was reduced quadratically with the elevation of this mineral in the ration $(\mathrm{P}<$ 
0.01) (Tables 2 and 3). We hypothesize that, with the increase of phosphorus in the feed, the absorption efficiency of this mineral decreases. This may be due to inactivation of active transport mechanisms, increasing the fecal loss of potentially digestible phosphorus (TANG et al., 2012). On the other hand, diets containing lower levels of phosphorus, although being used more efficiently, limited fish performance, demonstrating that limited supplementation is necessary to optimize performance (ROY; LALL, 2003; BÜNZEN, 2009; QUINTERO-PINTO et al., 2011).

The -LRP model was the best fit $(\mathrm{P}<0.10)$ for the deposition of protein, phosphorus, and ash, estimated at $0.55 \%, 0.59 \%$, and $0.46 \%$ of digestible phosphorus, respectively, from which there was a plateau. For the deposition of body fat, the elevation of digestible phosphorus provided a quadratic effect $(\mathrm{P}<0.05)$, increasing these variables until an estimated level of $0.90 \%$ of digestible phosphorus (Tables 4 and 5, Figure 2). The results corroborate the data for weight gain and specific growth rate, indicating that the elevation of phosphorus influenced the incorporation of all tissues. The increase in daily deposition of phosphorus and ash is justified by the fact that phosphorus is a component of hard tissues, such as bones, teeth, and scales, and soft tissues (FURUYA et al., 2008a; XIE et al., 2011). In addition, elevation of serum phosphorus levels activates the parathyroid hormone, which acts on the kidneys to reduce phosphate excretion, increasing its reabsorption in the bones and activating the osteoclastic cells responsible for bone modeling (bone mineralization) (ZIKIC, 2001; WERNER, 2010).

Table 4. Body deposition of protein (BDP), fat (BDF), phosphorus (PBD), and ash (BDA) in juvenile tambaqui per level of digestible phosphorus.

\begin{tabular}{ccccc}
\hline \multirow{2}{*}{$\begin{array}{c}\text { Level of digestible } \\
\text { phosphorus }(\%)\end{array}$} & \multicolumn{4}{c}{ Variable } \\
\cline { 2 - 5 } & BDP $\left(\mathrm{mg} \mathrm{day}^{-1}\right)$ & BDF $\left(\mathrm{mg} \mathrm{day}^{-1}\right)$ & PBD $\left(\mathrm{mg} \mathrm{day}^{-1}\right)$ & BDA $\left(\mathrm{mg} \mathrm{day}^{-1}\right)$ \\
\hline 0.27 & 133.11 & 79.57 & 6.64 & 31.66 \\
0.46 & 164.03 & 78.52 & 8.86 & 54.48 \\
0.67 & 181.96 & 91.54 & 10.44 & 57.20 \\
0.91 & 172.07 & 90.04 & 9.62 & 53.52 \\
1.04 & 184.82 & 96.59 & 9.72 & 53.61 \\
1.14 & 177.81 & 85.01 & 11.03 & 55.11 \\
\hline $\mathrm{P}>\mathrm{F}^{1}$ & 0.0024 & 0.0415 & 0.0001 & 0.0001 \\
\hline $\mathrm{CV}(\%)^{2}$ & 11.12 & 11.01 & 12.02 & 13.89 \\
\hline
\end{tabular}

${ }^{1} \mathrm{P}>\mathrm{F}$ - Significance of F-test for analysis of variance test;

${ }^{2} \mathrm{CV}$ - Coefficient of variation.

Table 5. Adjusted regression equations' $P$ values, coefficients of determination $\left(\mathrm{R}^{2}\right)$, and requirement percentages for body deposition of protein (BDP), fat (BDF), phosphorus (PBD), and ash (BDA) in juvenile tambaqui.

\begin{tabular}{lccccc}
\hline Variable & Model & Equation & $\mathrm{P}>\mathrm{F}$ & $\mathrm{R}^{2}$ & Requirement (\%) \\
\hline $\mathrm{BDP}\left(\mathrm{mg} \mathrm{day}{ }^{-1}\right)$ & Quadratic $^{1}$ & $\mathrm{BDP}=87.376+214.974 \mathrm{P}-120.42 \mathrm{P}^{2}$ & 0.0002 & 0.90 & 0.89 \\
$\mathrm{BDP}\left(\mathrm{mg} \mathrm{day}^{-1}\right)$ & $\mathrm{LRP}^{1}$ & $\mathrm{BDP}=179.1645-160.546(0.5518-\mathrm{P})$ & 0.0005 & 0.95 & 0.55 \\
$\mathrm{BDF}\left(\mathrm{mg} \mathrm{day}^{-1}\right)$ & Quadratic & $\mathrm{BDF}=62.401+63.703 \mathrm{P}-35.225 \mathrm{P}^{2}$ & 0.0348 & 0.60 & 0.90
\end{tabular}


continuation

\begin{tabular}{|c|c|c|c|c|c|}
\hline PBD (mg day $\left.{ }^{-1}\right)$ & Quadratic & $\mathrm{PBD}=3.2497+16.0362 \mathrm{P}-9.1194 \mathrm{P}^{2}$ & 0.0002 & 0.80 & 0.88 \\
\hline PBD (mg day $\left.{ }^{-1}\right)$ & $\mathrm{LRP}^{1}$ & $\mathrm{PBD}=9.8479-9.41863(0.5908-\mathrm{P})$ & 0.0005 & 0.95 & 0.59 \\
\hline $\mathrm{BDA}\left(\mathrm{mg}\right.$ day $\left.^{-1}\right)$ & Quadratic & $\mathrm{BDA}=7.450+124.003 \mathrm{P}-74.9623 \mathrm{P}^{2}$ & 0.0001 & 0.80 & 0.83 \\
\hline $\mathrm{BDA}\left(\mathrm{mg}\right.$ day $\left.^{-1}\right)$ & $\mathrm{LRP}^{1}$ & $\mathrm{BDA}=54.8602-118.467(0.4608-\mathrm{P})$ & 0.0001 & 0.98 & 0.46 \\
\hline
\end{tabular}

${ }^{1} \mathrm{LRP}$ - linear response plateau.

Figure 2. Deposition of body phosphorus in juvenile tambaqui per level of digestible phosphorus.

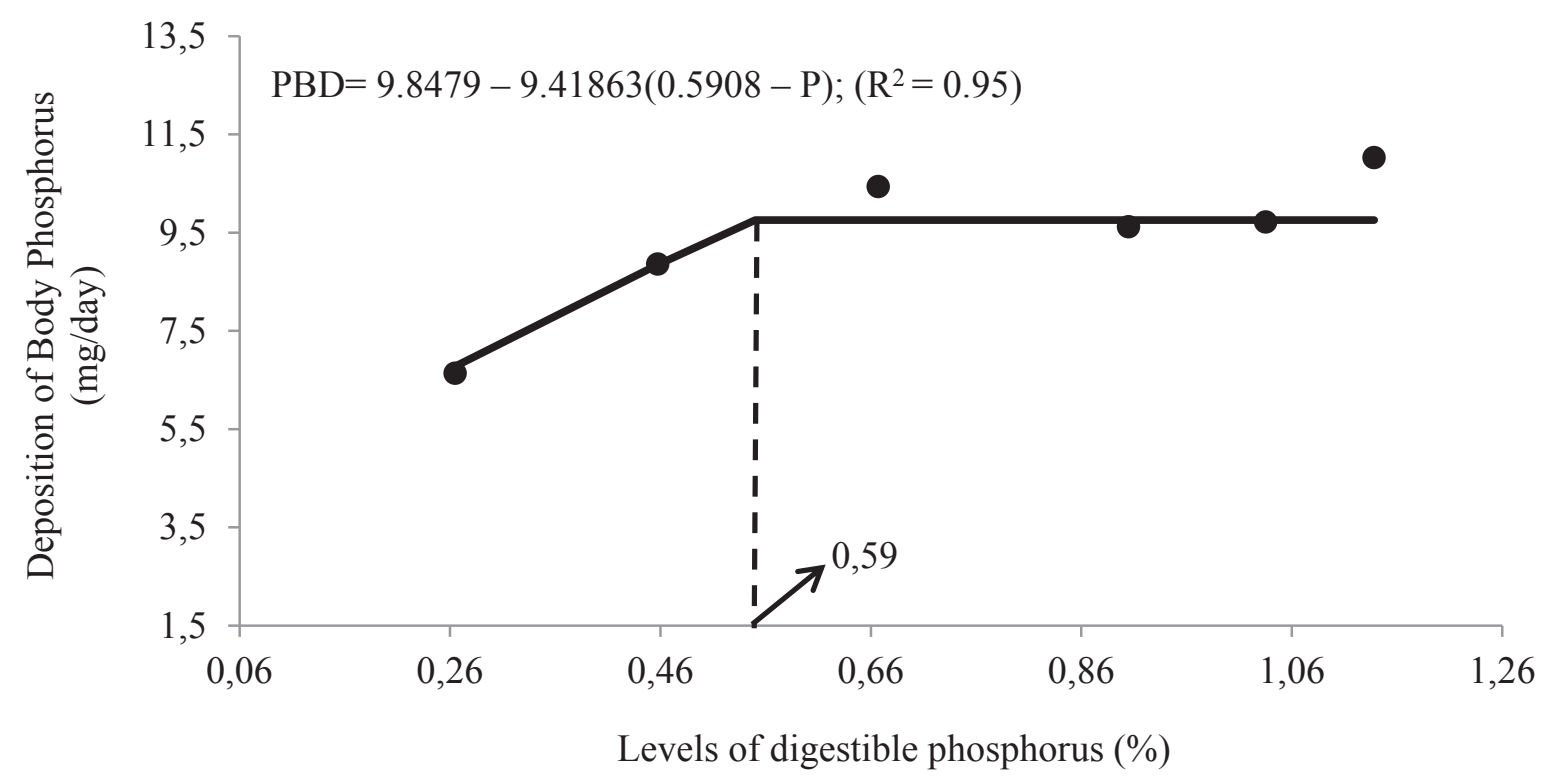

Although the activity of alkaline phosphatase was not evaluated in this study, there are some studies with fish that have reported positive effects between the levels of phosphorus in the diet and the activity of alkaline phosphatase (COLOSO et al., 2003; ARAÚJO et al., 2017). As alkaline phosphatase is related to the formation of osteoblasts, it can be inferred that the elevation of digestible phosphorus promoted an increase in alkaline phosphatase activity, resulting in the retention of phosphorus in the bones (XIE et al., 2011; ARAÚJO et al., 2017).

The increase in the deposition rates of body protein and fat is justified by the fact that phosphorus is a fundamental part of relevant organic molecules, such as phospholipids, phosphoproteins, coenzymes, nucleic acids, and energy rich compounds. Phosphorus also operates in enzymatic and hormonal systems, playing key roles in intermediary functions of the metabolism of amino acids, carbohydrates, and fat (LALL, 2002; QUINTERO-PINTO et al., 2011; SANTOS, 2012).

Given that phosphorus is the third-most costly nutrient in the feed, and one of the most polluting (ARAÚJO et al., 2012; BOMFIM, 2013), increasing its levels in the diet decreases its efficiency of use. Thus, the recommended level should provide lower fecal excretion and improve performance, protein deposition/use, and bone mineralization (ROY; LALL, 2003; BÜNZEN, 2009; QUINTERO-PINTO et al., 2011). The main variable for determining nutrient requirements by the dose-response method has been weight gain (NRC, 2011). According to 
recent meta-analysis studies (PRABHU et al., 2013; WANG et al., 2016), weight gain is one of the most reliable response criteria. In addition to weight gain, phosphorus deposition rate has also been used (SAKOMURA; ROSTAGNO, 2007; ABIMORAD et al., 2010; NRC, 2011). Accordingly, the recommendation of digestible phosphorus in diets for juvenile tambaqui that optimizes these variables is $0.55 \%$, which corresponds to the estimated level of $0.87 \%$ of total phosphorus. This value is lower than the $0.78 \%$ of digestible phosphorus that was estimated by a quadratic equation for the same species (SANTOS, 2012). The difference between recommendations may be due to the mathematical model, as the quadratic model can provide a higher estimate in relation to the LRP, as presented by Sakamura and Rostagno (2007) and Siqueira et al. (2009).

\section{Conclusion}

To optimize weight gain in juvenile tambaqui, the recommended level of digestible phosphorus in their diet is $0.55 \%$, which corresponds to an estimated level of $0.87 \%$ of total phosphorus.

\section{Acknowledgments}

We would like to thank the Fundação de Amparo à Pesquisa e ao Desenvolvimento Científico e Tecnológico do Maranhão for financing the project.

\section{References}

ABIMORAD, E. G.; FAVERO, G. C.; SQUASSONI, G. H.; CARNEIRO, D. Dietary digestible lysine requirement and essential amino acid to lysine ratio for pacu Piaractus mesopotamicus. Aquaculture Nutrition, Malden, v. 16, n. 4, p. 370-377, 2010.

ARAÚJO, D. S.; FERNANDES, E. A.; FAGUNDES, N. S. Substituição do fosfato bicálcico pelo fosfato monoamônio em dietas de frangos de corte. Revista Portuguesa Ciência Veterinária, v. 111, p. 173-176, 2012. ARAÚJO, J. G.; GUIMARÃES, I. G.; MOTA, C.
S.; PAULA, F. G.; CAFÉ, M. B.; PÁDUA, D. M. C. Dietary available phosphorus requirement for tambaqui, Clossoma macropomun, juveniles based on growth, haematology and bone mineralization. Aquaculture Nutrition, Malden, v. 23, n. 4, p. 822-832, 2017.

BENSTEAD, J. P.; HOOD, J. M.; WHELAN, N. V.; KENDRICK, M. R.; NELSON, D.; HANNINEN, A. F.; DEMI, L. M. Coupling of dietary phosphorus and growth across diverse fish taxa: a meta-analysis of experimental aquaculture studies. Ecology, Washington, v. 95, n. 10, p. 2768-2777, 2014.

BOERSMA, M.; ELSER, J. J. Too much of a good thing: on stoichiometrically balanced diets and maximal growth. Ecology, Washington, v. 87, n. 5, p. 1325-1330, 2006.

BOMFIM, M. A. D. Estratégias nutricionais para redução das excreções de nitrogênio e fósforo nos sistemas de produção de peixes no Nordeste: sustentabilidade ambiental e aumento da produtividade. Revista Científica de Produção Animal, Areia, v. 15, n. 2, p. 122-140, 2013.

BOMFIM, M. A. D.; LANNA, E. A. T.; DONZELLE, J. L.; QUADROS, M.; RIBEIRO, F. B.; SOUSA, M. P. Níveis de lisina, com base no conceito de proteína ideal, em rações para alevinos de tilápia-do-nilo. Revista Brasileira de Zootecnia, Viçosa, MG, v. 39, n. 1, p. 1-8, 2010.

BÜNZEN, S. Digestibilidade do fósforo de alimentos e exigência de fósforo digestivel de aves e suínos. 2009. Tese (Doutorado em Zootecnia) - Universidade Federal de Viçosa, Viçosa, MG.

BUREAU, B. P.; AZEVEDO, P. A.; TAPIA-SALAZAR, M.; CUZON, G. Pattern and cost of growth and nutrient deposition in fish and shrimp: potential implications and applications. In: Avances en nutrición acuícola $V$. Memorias del V Simposium Internacional de Nutrición Acuicola. Mexico, 2000. p. 111-139.

COLOSO, R. M.; KING, K.; FLETCHER, J. W.; HENDRIX, M. A.; SUBRAMANYAM, M.; WEIS, P.; FERRARIS, R. P. Phosphorus utilization in Rainbow trout (Oncorhynchus mykiss) fed practical diets and its consequences on efluente phosphorus levels. Aquaculture, Amsterdam, v. 220, n. 4, p. 801-820, 2003.

CYRINO, J. E. P.; BICUDO, A. J. A.; SADO, R. Y.; BORGHESI, R.; DAIRIKI, J. K. A piscicultura e o ambiente - o uso de alimentos ambientalmente corretos em piscicultura. Revista Brasileira de Zootecnia, Viçosa, MG, v. 39, p. 68-87, 2010. Suplemento Especial.

DAIRIKI, J. K.; SILVA, T. B. A. Revisão de literatura: exigências nutricionais do tambaqui - compilação de trabalhos, formulação de ração adequada e desafios 
futuros. Manaus: EMBRAPA Amazônia Ocidental, 2011. 44 p. (Embrapa Amazônia Ocidental, 91).

DETMANN, E.; SOUZA, M. A.; VALADARES FILHO, S. C.; QUEIROZ, A. C.; BERCHIELLI, T. T.; SALIBA, E. O. S.; CABRAL, L. S.; PINA, D. S.; LADEIRA, M. M.; AZEVEDO, J. A. G. Métodos para análise de alimentos - INCT - Ciência Animal. Visconde do Rio Branco: Suprema, 2012. 214 p.

FRACALOSSI, D. M.; CYRINO, J. E. P. Nutriaqua: nutrição e alimentação de espécies de interesse para a aquicultura brasileira. Florianópolis: Sociedade Brasileira de Aquicultura e Biologia Aquática, 2013. 375 p.

FURUYA, W. M.; FUJII, K. M.; SANTOS, L. D.; SILVA, T. S. C.; SILVA, L. C. R.; MICHELATO, M. Exigência de fósforo disponível para tilápia-do-Nilo (35 a $100 \mathrm{~g}$ ). Revista Brasileira de Zootecnia, Viçosa, MG, v. 37, n. 6, p. 961-966, 2008a.

FURUYA, W. M.; FUJII, K. M.; SANTOS, L. D.; SILVA, T. S. C.; SILVA, L. C. R.; SALES, P. J. P. Exigência de fósforo disponível para juvenis de tilápia-do-nilo. Revista Brasileira de Zootecnia, Viçosa, MG, v. 37, n. 9, p. $1517-$ 1522, 2008b.

FURUYA, W. M.; PEZZATO, L. E.; BARROS, M. M.; BOSCOLO, W. R.; CYRINO, J. E. P.; FURUYA, V. R. B.; FEIDEN, A. Tabelas brasileiras para nutrição de tilápias. Toledo: GFM, 2010. 100 p.

GUIMARÃES, I. G.; MARTINS, G. P. Nutrient requirements of two Amazonian aquacultured fish species, Colossoma macropomum (Cuvier, 1816) and Piaractus brachypomus (Cuvier, 1818): a mini review. Journal of Applied Ichthyology, Medford, v. 31, n. 4, p. 57-66, 2015.

LALL, S. P. The minerals. In: HALVER, J. E.; HARDY, R. W. (Ed.). Fish nutrition. San Diego: Academic Press, 2002. p. 260-301.

LALL, S. P.; LEWIS-MCCREA, L. M. Role of nutrients in skeletal metabolism and pathology in fish - an overview. Aquaculture, Amsterdam, v. 267, n. 1, p. 3-19, 2007.

LIMA, C. S. Proteína bruta em rações para alevinos de tambaqui e sua redução com suplementação de aminoácidos. 2013. Dissertação (Mestrado em Ciência Animal) - Universidade Federal do Maranhão, Chapadinha.

MENDONÇA, P. P.; COSTA, P. C.; POLESE, M. F.; VIDAL JÚNIOR, M. V.; ANDRADE, D. R. Efeito da suplementação de fitase na alimentação de juvenis de tambaqui (Colossoma macropomum). Archivos de Zootecnia, Córdoba, v. 61, n. 235, p. 437-448, 2012.
NATIONAL RESEARCH COUNCIL - NRC. Nutrient requirements of fish and shrimp. Washington: National Academy of Science, 2011. 376 p.

NOBLET, J. Avaliação energética em suínos. In: WORKSHOP LATINO-AMERICANO AJINOMOTO BIOLATINA DE NUTRIÇÃO DE AVES E SUÍNOS, 2001, Foz do Iguaçu. Anais... Foz do Iguaçu, 2001. p. $2-17$.

PEZZATO, L. E.; ROSA, M. J. S.; BARROS, M. M.; GUIMARÃES, I. G. Exigência em fósforo disponível para alevinos de Tilápia do Nilo. Ciência Rural, Santa Maria, v. 36, n. 5, p. 1600-1605, 2006.

PIMENTEL-RODRIGUES， P.; OLIVA-TELES， O. Phosphorus requeriments of gilthead sea bream (Sparus aurata L.) juveniles. Aquaculture Research, Oxford, v. 32, n. 1, p. 157-161, 2001.

PRABHU, P. A. J.; SCHRAMA, J. W.; KAUSHIK, S. J. Quantifying dietary phosphorus requirement of fish - a meta-analytic approach. Aquaculture Nutrition, Oxford, v. 19, n. 3, p. 233-249, 2013.

QUINTERO-PINTO, L. G.; PARDO-GAMBOA, B. S.; QUINTERO-PARDO, A. M. C.; PEZZATO, L. E. Exigências e disponibilidade de fontes de fósforo para tilápias. Veterinária e Zootecnia, Botucatu, v. 5, n. 2, p. 30-43, 2011.

RIBEIRO, F. B.; LANNA, E. A. T.; BOMFIM, M. A. D.; DONZELE, J. L.; FREITAS, A. S.; SOUSA, M. P.; QUADROS, M. Níveis de fósforo total em dietas para alevinos de tilápia-do-Nilo. Revista Brasileira de Zootecnia, Viçosa, MG, v. 35, n. 4, p. 1588-1593, 2006.

ROCHA, C. B.; PORTELINHA, M. K.; FERNANDES, J. M.; BRITTO, A. C. P.; SANTOS, J. D. M.; POUEY, J. L. O. F. Exigência de fósforo disponível para alevinos de peixe-rei (Odonthestes bonariensis) em uma dieta prática. In: CONGRESSO DE INICIAÇÃO CIENTÍFICA, ENPOS, 19., 12., 2010, Pelotas. Anais... Pelotas: XII ENPOS, 2010.

RODRIGUES, A. P. O. Nutrição e alimentação do tambaqui (Colossoma macropomum). Boletim do Instituto de Pesca, São Paulo, v. 40, n. 1, p. 135-145, 2014.

ROSTAGNO, H. S.; ALBINO, L. F. T.; DONZELE, J. L.; GOMES, P. C.; OLIVEIRA, R. F.; LOPES, D. C.; FERREIRA, A. S.; BARRETO, S. L. T.; EUCLIDES, R. F. Tabelas brasileiras para aves e suínos: composição de alimentos e exigências nutricionais. 3. ed. Viçosa, MG: Universidade Federal de Viçosa, 2011. 252 p.

ROY, P. K.; LALL, S. P. Dietary phosphorus requirement of juvenile haddock (Melanogrammus aeglefinus L.). Aquaculture, Amsterdam, v. 221, n. 4, p. 451-468, 2003. 
SAKOMURA, N. K.; ROSTAGNO, H. S. Métodos de pesquisa em nutrição de monogástricos. Jaboticabal: Funep, 2007. 283 p.

SANTOS, J. G. A. Exigência em fósforo digestivel para tambaqui (Colossoma macropomum). 2012. Tese (Doutorado em Ciência Animal) - Universidade Federal de Goiás. Escola de Veterinária e Zootecnia, Goiânia.

SIQUEIRA, J. C.; SAKOMURA, N. K.; NASCIMENTO, D. C. N.; FERNANDES, J. B. K. Modelos matemáticos para estimar as exigências de lisina digestível para aves de corte ISA Label. Revista Brasileira de Zootecnia, Viçosa, MG, v. 38, n. 9, p. 1732-1737, 2009.

SOUZA, F. O. Relação da metionina mais cistina com a lisina em rações para alevinos de tambaqui (Colossoma macromum). 2014. Dissertação (Mestrado em Ciência Animal) - Universidade Federal do Maranhão, Chapadinha.

STATISTICAL ANALYSIS SYSTEM - SAS. SAS user's guide:statistics. $5^{\text {th }}$ ed. Cary: SAS Institute, $2002.956 \mathrm{p}$.

TAKISHITA, S. S. Relações de treonina e triptofano com a lisina digestivel em rações para alevinos de tilápia do nilo. 2012. Tese (Doutorado em Zootecnia) Universidade Federal de Viçosa, Viçosa.

TANG, Q.; WANG, C.; XIE, C.; JIN, J.; HUANG, Y. Dietary available phosphorus affected growth performance, body composition, and hepatic antioxidant property of juvenile yellow catfish Pelteobagrus fulvidraco. The Scientific World Journal, Londres, v. 2012, p. 9, 2012.
WANG, C.; TANG, Q.; LUO, W.; ZHAO, Y. Modeling phosphorus metabolism in fish species: an example for juvenile yellow catfish, Pelteobagrus fulvidraco. Aquaculture International, Irlanda, v. 24, n. 1, p. 281294, 2016.

WERNER, P. R. Patologia geral veterinária aplicada. São Paulo: Roca, 2010. 384p.

XIE, N. B.; FENG, L.; LIU, Y.; JIANG, J.; JIANG, W. D.; HU, K.; ZHOU, X. Q. Growth, body composition, intestinal enzyme activities and microflora of juvenile Jian carp (Cyprinus carpio var. Jian) fed graded levels of dietary phosphorus. Aquaculture Nutrition, Oxford, v. 17, n. 6, p. 645-656, 2011.

XIE, D.; HAN, D.; ZHU, X.; YANG, Y.; JIN, J.; LIU, H.; XIE, S. Dietary available phosphorus requirement for on-growing gibel carp (Carassius auratus gibelio var. CAS III). Aquaculture Nutrition, Oxford, v. 23, n. 5, p. 1104-1112, 2017.

YAO, Y. F.; JIANG, M.; WEN, H.; WU, F.; LIU, W.; TIAN, J.; YANG, C. G. Dietary phosphorus requirement of gift strain of Nile tilapia Oreochromis niloticus reared in freshwater. Aquaculture Nutrition, Oxford, v. 20, n. 3, p. 273-280, 2014.

ZIKIC, R. V. Activities of superoxide dismutase and catalase in erytrocyte and plasma transaminases of goldfish (Carassius auratus gibelio Bloch.) exposed to cadmium. Physiological Resarch, República Checa, v. 50, n. 1, p. 105-111, 2001. 